\title{
Indaziflam: Leaching and control of Urochloa plantaginea in applications on coffee litter with different rainfall simulations
}

\author{
Paulo Vinicius da Silva1 (iD), Mayck José dos Santos ${ }^{2}$ (D), Sergio Mateus Tronquini ${ }^{2}$, Ana Ligia Giraldeli ${ }^{\text {(iD), }}$ \\ Roque de Carvalho Dias ${ }^{4}$ (D), Estela Maris Inácio ${ }^{5}$ (D) , Patricia Andrea Monquero ${ }^{6}$ (D)
}

\author{
${ }^{1}$ Universidade Federal da Grande Dourados/UFGD, Faculdade de Ciências Agrárias, Dourados, MS, Brasil \\ ${ }^{2}$ Centro Universitário da Fundação de Ensino Octavio Bastos/UNIFEOB, Faculdade de Agronomia, São João da Boa Vista, SP, Brasil \\ ${ }^{3}$ Universidade Estadual de Londrina/UEL, Departamento de Agronomia, Londrina, PR, Brasil \\ "Universidade Estadual Paulista "Júlio de Mesquita Filho"/UNESP, Faculdade de Ciências Agronômicas, Botucatu, SP, Brasil \\ ${ }^{5}$ Universidade Estadual de Ponta Grossa/UEPG, Ponta Grossa, PR, Brasil \\ ${ }^{6}$ Universidade Federal de São Carlos/UFSCar, Centro de Ciências Agrárias/CCA, Araras, SP, Brasil \\ Contact authors: paulovsilva@ufgd.edu.br, mayck.santos@sou.unifeob.edu.br, smtronquini@gmail.com, ana.giraldeli@uel.br, roquediasagro@gmail.com, estelainacio@hotmail.com, \\ pamonque@cca.ufscar.br \\ Received in September 4, 2020 and approved in December 9, 2020
}

\section{ABSTRACT}

Coffee litter and the rain that occurs after the application of pre-emergence herbicides impact on their leaching and weed control effectiveness. The objective of this study was to evaluate the leaching and control effectiveness of indaziflam, applied on coffee litter, and under simulations of different amounts of rainfall. Two experiments in greenhouse were conducted with the application of indaziflam ( $0.1 \mathrm{~kg}$ of active ingredient - a.i. - ha $\left.{ }^{-1}\right)$, in a completely randomized design. The first involved the leaching of the herbicide using Urochloa plantaginea as a bioindicator, in a $8 \times 4$ factorial arrangement, with eight depths in the PVC column $(0-0.05 ; 0.05-0.1 ; 0.1-0.15 ; 0.15-0.2 ; 0.2-0.25 ; 0.25-0.3 ; 0.3-0.35 ; 0.35-0.4 \mathrm{~m})$ and four amounts of straw $(0 ; 1 ; 3$ and $\left.5 \mathrm{t} \mathrm{ha}^{-1}\right)$, this factor was isolated for rainfall simulations $(10,20$ and $40 \mathrm{~mm})$. The second experiment tested the effectiveness in controlling $U$. plantaginea, in a $4 \times 3$ factorial arrangement, with four amounts of litter $\left(0 ; 1 ; 3\right.$ and $\left.5 \mathrm{t} \mathrm{ha}^{-1}\right)$ and three amounts of rainfall $(10,20$ and 40 mm). Both experiments had four repetitions and controls without application of the herbicide. In leaching, a greater effect of indaziflam was found at a depth of 0-0.05 $\mathrm{m}$, and the higher the simulated rainfall, the greater the phytotoxicity observed in U. plantaginea, with $39.75 \%, 52.50 \%$ and $92.06 \%$, for rainfall amounts of 10,20 and $40 \mathrm{~mm}$, respectively. U. plantaginea showed high susceptibility to control by the herbicide indaziflam, and the lowest control, $82 \%$, was observed when indaziflam was applied on $5 \mathrm{t} \mathrm{ha}^{-1}$ with simulation of rainfall at $10 \mathrm{~mm}$. The increase in the amount of litter on the soil surface, combined with lower amounts of rainfall can reduce the leaching of indaziflam and the control of $U$. plantaginea.

Key words: Alexandergrass; Coffee plantation; Pre-emergence; Transport.

\section{INTRODUCTION}

Weed infestation in coffee plantations can cause interference with coffee crop, affecting crop management in relation to: (1) interference with the harvesting process (mechanized or manual); (2) photosynthetic apparatus of coffee plants and (3) direct competition for resources within the same space (Dias; Alves; Lemes, 2005; Carvalho; Alves; Bianco, 2013; Ronchi; Silva, 2003; Ronchi; Silva, 2014; Oliveira; Freitas; Vieira, 2009; Da Silva et al., 2019).

Among the main forms of weed management in coffee cultivation, we have the use of herbicides, the pre-emergence ones provide control of germination flows, thus reducing the number of post-emergence herbicide applications (Ronchi; Ferreira; Silva, 2014).

In this context, indaziflam is a pre-emergence herbicide option in coffee crop, which presents the mechanism of action to inhibit cellulose biosynthesis (chemical class "alkylazine") (Tompkins, 2010). This herbicide has a broad spectrum of action, controlling both monocots and eudicots (Brosnan et al., 2011; Brosnan et al., 2012), and its greatest effectiveness is related to the control of monocot weeds (Amim et al., 2014; Malardo et al., 2017; Da Silva et al., 2020). As for the physical and chemical characteristics, it has low water solubility $\left(2,010 \mathrm{mg} \mathrm{L}^{-1}\right)$ and high Kow (2.0 at $\mathrm{pH}=2.0 ; 2.8$ at $\mathrm{pH}=4$ and $\mathrm{pH}=9$ ) (Rodrigues; Almeida, 2018).

Because of these physical and chemical characteristics, indaziflam is classified as lipophilic, and should be positioned in the rainy season, with applications in humid and clod-free soil, directed between the rows of the coffee crop through a directed jet at the pre-emergence of weeds (Rodrigues; Almeida, 2018). In this context, indaziflam applied on coffee litter can result in less transport of the herbicide to the soil, resulting in its low availability in the soil solution, and consequently in the reduction of leaching and effectiveness in controlling weeds.

Therefore, the first rain on the environment after applying indaziflam on the litter has a great influence on the mobility and effectiveness of this product, as according to Maciel and Velini (2005), initial $20 \mathrm{~mm}$ have the maximum capacity for transporting highly soluble herbicides from straw to soil. However, as indaziflam is characterized as a lipophilic product, there may be a need for an initial rainfall greater than $20 \mathrm{~mm}$, to promote this transport from the coffee litter to the soil and, consequently, result in its incorporation by leaching 
(Da Silva, 2018). Ideally, herbicides should remain in the first $0.1 \mathrm{~m}$ of the soil profile, where most weed seeds and disseminates are concentrated, because in leaching scenarios greater than this depth, there may be water table contamination and reduction in the effectiveness of weed control (Silva; Monquero, 2013).

In view of the above, there is a clear need to determine the correct application of indaziflam on coffee litter and the amount of rainfall required to promote its correct mobility and/or transport in the soil profile. Thus, the objective of this study was to evaluate the leaching and control effectiveness of indaziflam, when applied on coffee litter under simulations of different amounts of rainfall.

\section{MATERIAL AND METHODS}

\subsection{Site of the experiment}

Experiments were conducted in a greenhouse, belonging to the Octávio Bastos University Center (UNIFEOB), located in the city of São João da Boa Vista, state of São Paulo (SP) $\left(21^{\circ} 58^{\prime} 10^{\prime \prime} \mathrm{S}\right.$ and $\left.46^{\circ} 47^{\prime} 56^{\prime \prime} \mathrm{O}\right)$. The climate of the region is hot and temperate, classified as $\mathrm{Cwa}$, with average annual rainfall and temperature of $20.1^{\circ} \mathrm{C}$ and $1,493 \mathrm{~mm}$, respectively (Köppen; Geiger, 1928). The experiments were carried out at two different times, the first in July 2019 and the second in September 2019.

The soil used in both tests was a dystrophic Red Latosol, with a sandy texture (Santos et al., 2018) removed from the arable layer, previously sieved and with no history of residual herbicide applications. Physical and chemical properties of the soil were analyzed by laboratory (Table 1).

\subsection{Obtaining and preparing coffee litter}

Coffee litter used in the present study was removed from a coffee plantation in full production, variety Catuai Vermelho, transplanted in September 2001, with an average productivity of 50 bags ha ${ }^{-1}$, belonging to the Bela Vista site located in the city of Ibitiúra de Minas, in the state of Minas Gerais (MG). The material was collected before herbicide application, thus avoiding contamination of the litter. Subsequently, this litter was air-dried, chopped manually with the aid of scissors and weighed, in order to establish the proportional amounts of litter in tons per hectare of each treatment.

\subsection{Leaching of indaziflam when applied on coffee litter and subjected to different amounts of rainfall}

The experimental units consisted of soil column mounted on PVC pipes, $0.10 \mathrm{~m}$ in diameter and $0.50 \mathrm{~m}$ in length, which were filled with undisturbed soil samples. The experimental design used was completely randomized in $8 \mathrm{x}$ 4 factorial arrangement, with eight depths of the soil profile $(0-0.05 ; 0.05-0.1 ; 0.1-0.15 ; 0.15-0.2 ; 0.2-0.25 ; 0.25-0.3 ; 0.3-$ $0.35 ; 0.35-0.4 \mathrm{~m})$ and four amounts of straw $(0 ; 1 ; 3$ and 5 $\left.\mathrm{t} \mathrm{ha}^{-1}\right)$. The factor was isolated for each of the three rainfall simulations $(10,20$, and $40 \mathrm{~mm})$, with four repetitions, in addition to the control that was not applied with the herbicide.

These soil cores were coupled to PVC pipes of $10 \mathrm{~cm}$ in diameter with sufficient height to accommodate the different amounts of litter. In the treatments that represented $0 \mathrm{t} \mathrm{ha}^{-1}$ litter, the PVC piece was not attached (the herbicide was applied directly to the top of the column and, consequently, to the soil). The pipes, as well as the coupled parts, were internally wrapped with a layer of paraffin, in order to avoid lateral drainage of the soil solution. At the bottom, 50\% shade cloths were used to hold the soil and allow drainage.

Indaziflam ( $0.1 \mathrm{~kg}$ of active ingredient - a.i. - ha $\left.{ }^{-1}\right)$, was applied in pre-emergence, on soil and dry litter, with a $\mathrm{CO}_{2}$ pressurized backpack sprayer at constant pressure, with fan nozzles AI 110.015, pressure of $3.16 \mathrm{kgf} \mathrm{cm}^{-2}$, with a spray volume of 200 $\mathrm{L} \mathrm{ha}^{-1}$. Upon application, the temperature was $29^{\circ} \mathrm{C}$, the relative humidity was $40 \%$ and the wind speed was $3 \mathrm{~m} \mathrm{~s}^{-1}$. Then, soil cores were subjected to three rainfall simulations equivalent to 10,20 , and $40 \mathrm{~mm}$. These simulations were carried out with the aid of a rain simulator, with rainfall intensity of $1 \mathrm{~mm} \mathrm{~min}^{-1}$, during the time necessary to apply the different water volumes.

Promptly, after the rainfall simulations, the irrigation system was turned off, and the soil columns were at rest for $72 \mathrm{~h}$, enough time for the straw to be dry. At that time, the structure attached to the PVC pipe was carefully removed along with the straw.

Then the columns were opened and placed in a horizontal position. Each column was divided into eight $0.05 \mathrm{~m}$ sections $(0-0.05 ; 0.05-0.1 ; 0.1-0.15 ; 0.15-0.2 ; 0.2-$ $0.25 ; 0.25-0.3 ; 0.3-0.35 ; 0.35-0.4 \mathrm{~m})$, measured from the surface where the herbicides were applied. In each section, a continuous row of seeds of Urochloa plantaginea (Link) RD Webster (alexandergrass) was sown; seeds were positioned at $0.02 \mathrm{~m}$ each other, serving as a bioindicator of the presence of indaziflam in different soil depths.

Table 1: Result of the chemical analysis of the soil of the experimental area, at a depth of 0-0.2 m. São João da Boa Vista, SP.

\begin{tabular}{ccccccccccccc}
\hline $\mathrm{pH}\left(\mathrm{CaCl}_{2}\right)$ & $\mathrm{Al}$ & $\mathrm{H}+\mathrm{Al}$ & $\mathrm{P}($ resin) & $\mathrm{K}$ & $\mathrm{Ca}$ & $\mathrm{Mg}$ & $\mathrm{SB}$ & $\mathrm{CEC}$ & $\mathrm{V}$ & Sand & Silt & Clay \\
\hline 6.00 & $<1.5$ & 16.0 & 51.0 & 4.0 & 26.0 & 10.0 & 59.0 & 75.0 & 79.0 & 66.9 & 7.9 & 25.2 \\
\hline
\end{tabular}

Units: Al, $\mathrm{H}+\mathrm{Al}, \mathrm{K}, \mathrm{Ca}, \mathrm{Mg}, \mathrm{SB}$ and CEC $\left(\mathrm{mmol}_{\mathrm{c}} \mathrm{dm}^{-3}\right) ; \mathrm{P}$ (resin) $\left(\mathrm{mg} \mathrm{dm}^{-3}\right) ; \mathrm{V}$, clay, silt, sand (\%)

Source: Brazilian Institute of Analysis (IBRA) 
At 7, 10 and 21 days after $U$. plantaginea emergence (DAE), seedling control assessments were performed. This assessment was based on qualitative criteria, according to Alam (1974), which uses a percentage score scale, where 0 (zero) corresponds to no injury to the plant and 100 (one hundred) to plant death.

In addition to the visual analysis, at 21 DAE, shoot dry matter of $U$. plantaginea seedlings was determined, where the plants were cut close to the ground and taken to a forced air oven at $60{ }^{\circ} \mathrm{C}$ for 48 hours.

\subsection{Control of Urochloa plantaginea by indaziflam in different amounts of coffee litter and under different rainfall simulations}

The experimental design used was a 4 × 3 factorial completely randomized design, with four amounts of litter $(0$; 1; 3 and $\left.5 \mathrm{tha}^{-1}\right)$ and three amounts of rainfall (10, 20, and 40 $\mathrm{mm}$ ), with four repetitions, in addition to the control, with no herbicide application.

The experimental units consisted of plastic polyethylene pots with a capacity of $10 \mathrm{~L}$, filled with soil. Then, seeds of $U$. plantaginea were sown in the pots, in sufficient number to provide 10 plants per pot, according to the previous germination information provided by the company Agrocosmos, where weed seeds were purchased. Thus, $0.00012 \mathrm{~kg}$ seeds were used. Sowing was performed at a depth of $0.01 \mathrm{~cm}$ of the soil profile.

After filling the pots and sowing the weed, the four different litter amounts $\left(0 ; 1 ; 3\right.$ and $\left.5 \mathrm{tha}^{-1}\right)$ were placed on the pot surfaces. Then, indaziflam $\left(0.1 \mathrm{~kg}\right.$ a.i. $\left.\mathrm{ha}^{-1}\right)$ was applied at pre-emergence on soil and dry litter, with a $\mathrm{CO}_{2}$ pressurized backpack sprayer at constant pressure of $3.16 \mathrm{kgf} \mathrm{cm}^{-2}$, with flat fan nozzles AI110.015, and spray volume of $200 \mathrm{~L} \mathrm{ha}^{-1}$. Upon application, the temperature was $30^{\circ} \mathrm{C}$, the relative humidity was $50 \%$ and the wind speed was $1 \mathrm{~m} \mathrm{~s}^{-1}$.

After applying the treatments, experimental units were subjected to three different rainfall simulations (10, 20 and $40 \mathrm{~mm}$ ). This simulation was carried out using a sprinkler irrigation system at a flow rate of $1 \mathrm{~L} \mathrm{~min}^{-1}$, in which the pots were irrigated long enough to provide the respective amounts of rainfall.

Subsequently, irrigation was turned off for 48 hours, thus allowing the straw on the surface of the pots to dry. Thus, litter was removed from the pots, in order to study only the interception of the herbicide and not the effect of physical barrier as suppression of germination. After this process, pots were maintained with daily irrigation equivalent to $10 \mathrm{~mm}$.

The visual assessments of weed control occurred at 7 , 14, 21, 28 and 35 DAE and were based on the visual scale of Alam (1974), which uses a percentage score scale, where zero corresponds to the absence of control $(0 \%)$ and 100 corresponds to plant death $(100 \%)$. At 35 DAE, shoot dry matter (MSPA) was evaluated. For this, plants remaining in the treatments were cut close to the ground, packed in paper bags and dried in a forced air oven $\left(70^{\circ} \mathrm{C}\right)$ for 48 hours, to constant weight.

\subsection{Statistical analysis}

For both experiments, data obtained were tested by analysis of variance by $\mathrm{F}$ test, and the means were compared by Tukey's test, using the statistical software AgroEstat ${ }^{\circledR}$ (Barbosa; Maldonado Júnior, 2009). For the leaching experiment, when the factor interaction was significant, regression curves were constructed using the SIGMAPLOT software.

\section{RESULTS}

\subsection{Leaching of indaziflam when applied on coffee litter and subjected to different amounts of rainfall}

Factor interaction between the different amounts of straw and soil depth for rainfall of $10 \mathrm{~mm}$, inherent to the control and dry matter, is seen in Figure 1. Regardless of the amount of straw on the soil surface, indaziflam was only identified up to $10 \mathrm{~cm}$ in the soil profile. The highest percentages of $U$. plantaginea phytotoxicity were observed at a depth of $0-0.05 \mathrm{~m}$, for straw amounts $0,1,3$, and $5 \mathrm{tha}^{-1}$, with $61.50 ; 35.00 ; 33.75$ and $28.75 \%$, respectively. Regardless of the depth or amount of straw, phytotoxicity of $U$. plantaginea was less than $80 \%$.

In the evaluation of leaching (control and dry matter), in the simulation of $20 \mathrm{~mm}$ rainfall, the presence of indaziflam was also found only up to the first $0.1 \mathrm{~m}$ depth. There was a gradual reduction in leaching at a depth of $0-0.05 \mathrm{~m}$, as the amount of straw present on the soil surface increased. In the $20 \mathrm{~mm}$ rainfall, the highest percentage of $U$. plantaginea phytotoxicity was observed in the absence of straw at a depth of 0-0.05 m, however it was still below 80\% (Figure 2). Regarding leaching by simulation of $40 \mathrm{~mm}$ rainfall, results of control and dry matter are illustrated in Figure 3. In the application directly to the soil $\left(0 \mathrm{t} \mathrm{ha}^{-1}\right)$, the presence of the herbicide was observed to the depth $0.35-0.40 \mathrm{~m}$, but the percentages of $U$. plantaginea phytotoxicity showed a gradual reduction as the depth increased, with averages greater than $80 \%$ only until the depths of $0.1-0.15 \mathrm{~m}$. In the application on $1 \mathrm{t} \mathrm{ha}^{-1}$, reduction in the phytotoxicity percentage was also found, with the presence of the herbicide up to $0.2-0.25 \mathrm{~m}$ depth. In the amounts of 3 and $5 \mathrm{t} \mathrm{ha}^{-1}$ litter, indaziflam concentrated only in the depth of $0-0.05 \mathrm{~m}$, and for $5 \mathrm{t} \mathrm{ha}^{-1}$, the control was less than $80 \%$, with $75.25 \%$. 

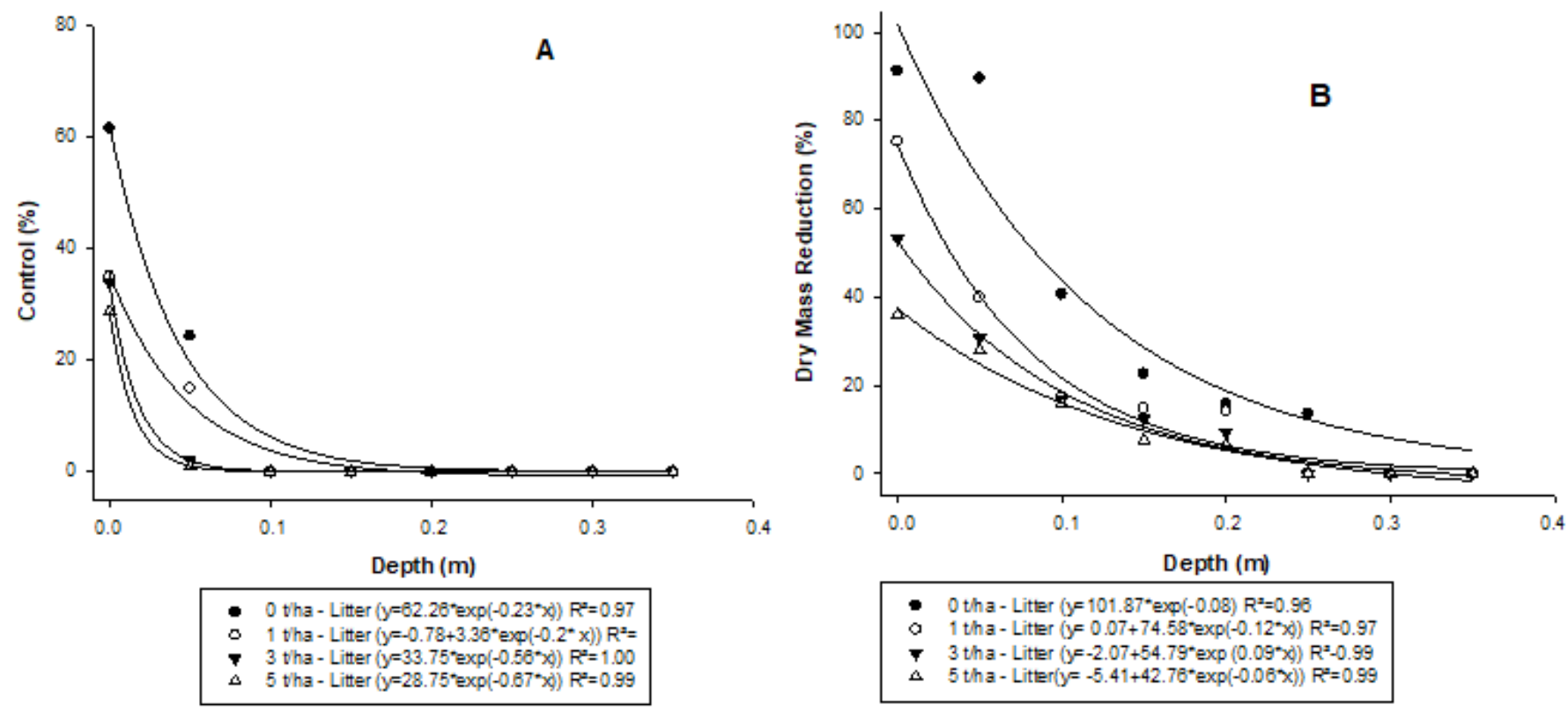

Figure 1: Leaching of indaziflam applied on different amounts of coffee litter and under simulated rainfall of $10 \mathrm{~mm}$. Control (a) and dry mass reduction (b).
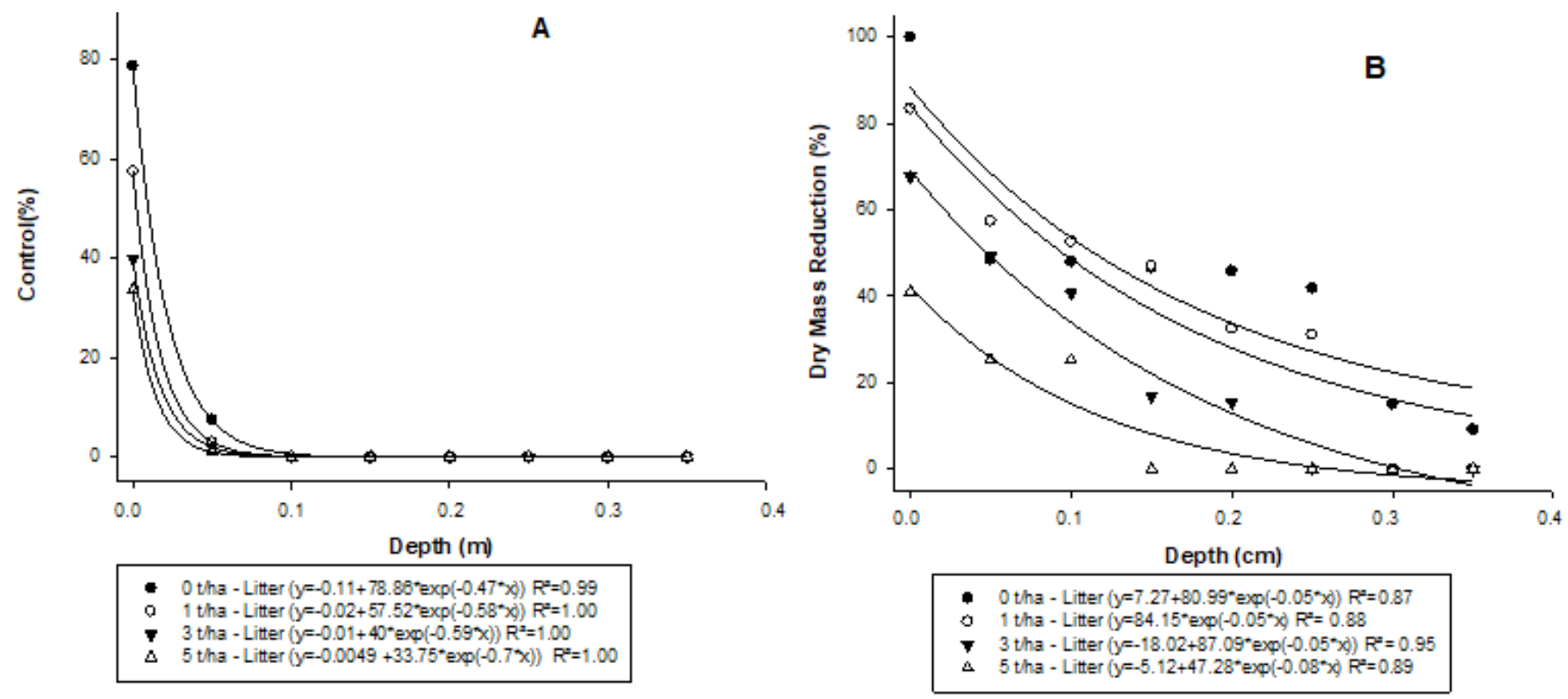

Figure 2: Leaching of indaziflam applied on different amounts of coffee litter and under simulated rainfall of $20 \mathrm{~mm}$. Control (a) and dry mass reduction (b).

\subsection{Control of Urochloa plantaginea by} indaziflam in different amounts of coffee litter and rainfall simulations

Regarding the control, the results of the breakdown of the factor litter amount can be seen in Table 2. In the amounts of litter $0,1,3 \mathrm{tha}^{-1}$, no statistical differences were detected each order. In the application of indaziflam on $5 \mathrm{t} \mathrm{ha}^{-1}$ resulted in a control of $90.16 \%$ of $U$. plantaginea
However, regardless of the amount of straw, the control was considered excellent, with percentages greater than $90 \%$.

The results inherent to the breakdown of the factor rainfall amount are listed in Table 3. As the amount of simulated rainfall increased, after the application of the herbicide, the control also showed higher percentages, with the lowest control being observed in the rainfall simulation of $10 \mathrm{~mm}$, with $94.18 \%$. 

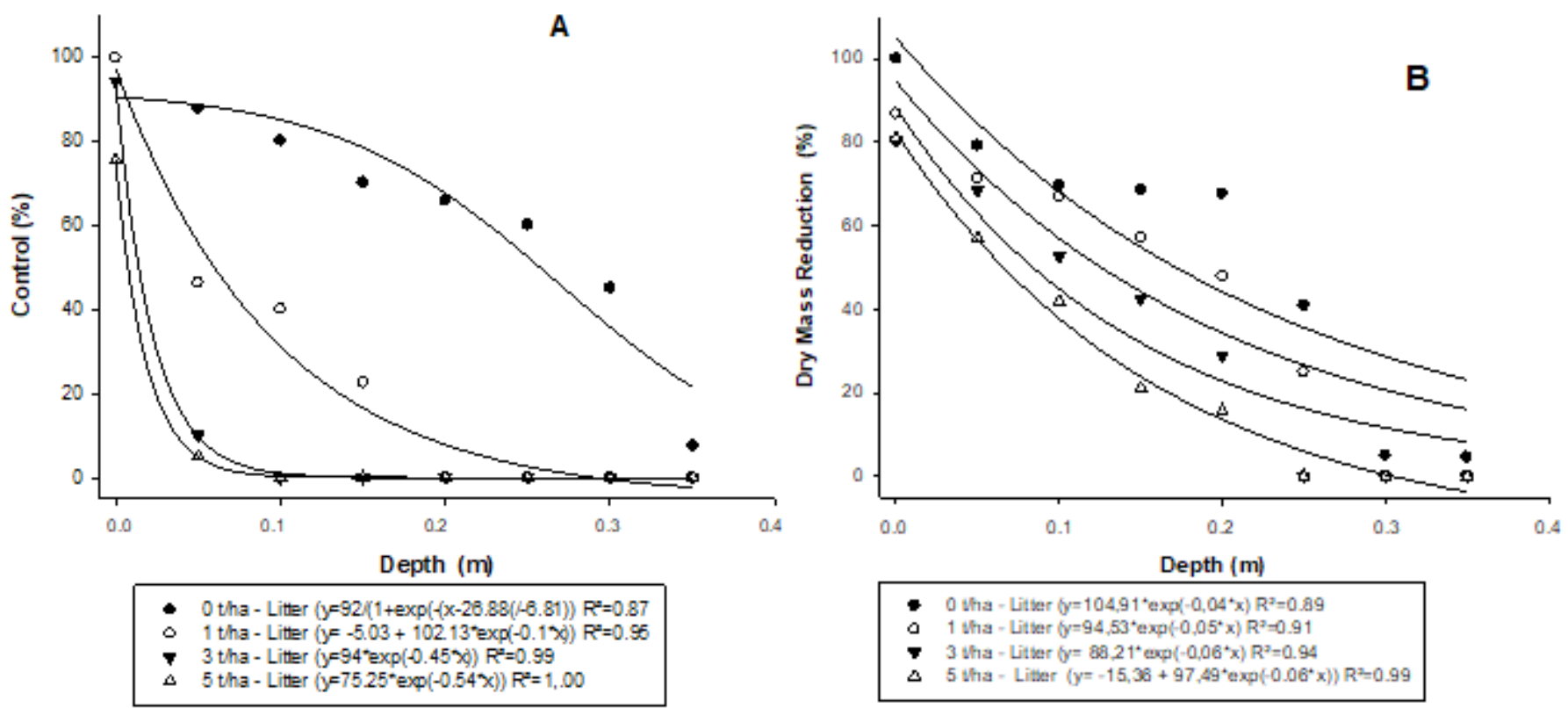

Figure 3: Leaching of indaziflam applied on different amounts of coffee litter and under simulated rainfall of $40 \mathrm{~mm}$. Control (a) and dry mass reduction (b).

Table 2: Breakdown of the factor litter amount to control Urochloa plantaginea.

\begin{tabular}{cc}
\hline Litter $\left(\mathbf{t ~ h a}^{-1}\right)$ & Control (\%) \\
\hline $\mathbf{0}$ & $100.00 \mathrm{a}$ \\
$\mathbf{1}$ & $99.00 \mathrm{a}$ \\
$\mathbf{3}$ & $97.33 \mathrm{a}$ \\
$\mathbf{5}$ & $90.16 \mathrm{~b}$
\end{tabular}

$$
\begin{gathered}
\operatorname{LSD}(5 \%)=3.91 \\
\mathrm{~F}=18.73 * * \\
\text { C.V. }(\%)=3.68
\end{gathered}
$$

** Significance level set at $1 \%$ probability by F-test; NS - Nonsignificant; C.V.- Coefficient of variation; LSD - Least significant difference at $5 \%$. Means followed by different lower-case letters are significantly different by Tukey's test at $5 \%$ significance.

Table 3: Breakdown of the factor rainfall amount to control the aerial part of Urochloa plantaginea.

\begin{tabular}{ccc}
\hline Rainfall (mm) & Control (\%) \\
\hline $\mathbf{1 0}$ & $94.18 \mathrm{~b}$ \\
$\mathbf{2 0}$ & $96.93 \mathrm{ab}$ \\
$\mathbf{4 0}$ & $98.75 \mathrm{a}$ \\
\hline \multicolumn{3}{c}{ LSD $(5 \%)=3.07$} \\
$\mathrm{~F}=6.67 * *$ \\
& C.V. $(\%)=3.68$ \\
\hline
\end{tabular}

** Significance level set at $5 \%$ probability by F-test; NS - Non-significant; C.V.- Coefficient of variation; LSD - Least significant difference at $5 \%$. Means followed by different lower-case letters are significantly different by Tukey's test at $5 \%$ significance.
In the factor interaction between the amount of litter and rainfall, data are presented in Table 4 . The only treatment in which there was a statistical difference was in the application of indaziflam on $5 \mathrm{t} \mathrm{ha}^{-1}$ and under a simulated rainfall of 10 $\mathrm{mm}$, which resulted in $82 \%$ control of $U$. plantaginea, the lowest obtained between the treatments.

For dry matter reduction data, no statistical differences were detected in the factor interaction between the amount of rainfall and straw.

Table 4: Factor interaction for the control of Urochloa plantaginea through the application of indaziflam on different amounts of litter under different amounts of simulated rainfall.

\begin{tabular}{cccc}
\hline \multirow{2}{*}{ Litter $\left(\mathrm{t} \mathrm{ha}^{-1}\right)$} & \multicolumn{3}{c}{ Rainfall $(\mathbf{m m})$} \\
\cline { 2 - 4 } & $\mathbf{1 0}$ & $\mathbf{2 0}$ & $\mathbf{4 0}$ \\
\hline $\mathbf{0}$ & $100.00 \mathrm{aA}$ & $100.00 \mathrm{aA}$ & $100.00 \mathrm{aA}$ \\
$\mathbf{1}$ & $98.5 \mathrm{aA}$ & $98.75 \mathrm{aA}$ & $100.00 \mathrm{aA}$ \\
$\mathbf{3}$ & $96.25 \mathrm{aA}$ & $98.75 \mathrm{aA}$ & $100.00 \mathrm{aA}$ \\
$\mathbf{5}$ & $82.00 \mathrm{bB}$ & $93.25 \mathrm{aA}$ & $100.00 \mathrm{aA}$ \\
\hline $\mathrm{LSD}_{\text {litter }}=6.77$ & \multicolumn{3}{c}{$\mathrm{LSD}_{\text {rainfall }}=6.14$} \\
\hline $\mathrm{F}_{\text {litter }} 18.73^{* *}$ & \multicolumn{4}{c}{$\mathrm{F}_{\text {rainfall }} 6.67^{*}$} \\
\hline \multicolumn{4}{c}{ C.V. $(\%)=3.68$} \\
\hline
\end{tabular}

** Significance level set at $1 \%$ probability by F-test; * Significance level set at $5 \%$ probability by F-test; NS - Non-significant; C.V.- Coefficient of variation; LSD - Least significant difference at $5 \%$. Means followed by different lower-case letters, in the same column, and upper-case letters, in the same row, are significantly different by Tukey's test at $5 \%$ significance. 


\section{DISCUSSION}

Leaching of indaziflam in the simulated rainfall amounts of 10 and $20 \mathrm{~mm}$ was not sufficient to promote the transposition of the herbicide from the surface where it was applied (soil or litter) to soil solution, resulting in insufficient incorporation in the first $0.10 \mathrm{~m}$ of depth, because regardless of litter amount, the phytotoxicity percentages of $U$. plantaginea were less than $80 \%$.

These results were expected, as indaziflam is an herbicide with high Kow (2.88) and, consequently, a high affinity for lipids and plant residues, so its application on these materials can result in adsorption and/or interception, and reduce the amount of product reaching the soil, which may affect its leaching (Tompkins, 2010)

Da Silva (2018), studied the dynamics of indaziflam in sugarcane straw, and found an adsorption of indaziflam above $80 \%$ regardless of its concentration $(0.125 ; 0.5$ and 1 ppm). Regarding interception, the application of indaziflam on the amounts of straw of 5 and $10 \mathrm{t} \mathrm{ha}^{-1}$ with rainfall of 24 $\mathrm{mm}$ resulted in a maximum removal of only $25 \%$ herbicide. This indicates that the high Kow and low water solubility of this herbicide can culminate in greater adsorption and/or interception of this product in the straw.

Thus, for greater transposition of indaziflam from the coffee litter to the soil, with subsequent leaching in depth, it may be necessary to have greater amounts of rainfall after the application of this herbicide (Guerra et al., 2016). This behavior was proven in the present experiment, as the $40 \mathrm{~mm}$ rainfall resulted in higher phytotoxicity of $U$. plantaginea in the soil columns. However, even with the $40 \mathrm{~mm}$ rainfall simulation, the gradual increase in the amount of litter present on the soil surface, drastically reduced the leaching of indaziflam at different depths.

These results indicate that although there is a minimum recommendation of $20 \mathrm{~mm}$ rainfall after the application of highly soluble herbicides on plant residues, this amount of rainfall can be even greater for lipophilic herbicides, such as indaziflam, especially when applied in high amounts of coffee litter. Besides that, the results obtained demonstrate the need for rainfall to incorporate indaziflam in applications directly on soil and on litter.

These results corroborate Clark et al. (2019), who applied indaziflam on straw of Bromus tectorum and performed simulations of rainfall and found that a greater amount of the herbicide was intercepted when the applied on large amounts of straw, and the recovery of indaziflam intercepted in the straw was greater when the rainfall simulation occurred immediately after application of the product and with greater amounts of simulated rainfall.

When indaziflam was applied on $0 \mathrm{t} \mathrm{ha}^{-1}$ litter and with $40 \mathrm{~mm}$ simulated rainfall, the herbicide was leached to a depth of $0.35-0.4 \mathrm{~m}$ in the soil column. This result was expected, as the soil used in this experiment is sandy, with $66.9 \%$ sand, which may have resulted in less adsorption of the product along the soil depths. Associated with this, the absence of litter as a physical barrier, may also have favored the transport of the herbicide along the soil column.

Sebastian, Nissen and De Souza Rodrigues (2016) reported that indaziflam has a positive correlation for organic matter adsorption, resulting in its lower availability in soil solution, impacting its effectiveness in controlling weeds. The authors also detected a negative correlation for clay adsorption. Da Silva (2018) also observed a positive correlation for organic matter adsorption and a negative, for clay.

Amim et al. (2014) found that the soil influences the effectiveness of indaziflam in weed control. Digitaria horizontalis Willd. and Panicum maximum Jacq. were effectively controlled on all soils. Rottboellia cochinchinensis (Lour.) Clayton was efficiently controlled in clay loam and sandy soils (in all doses); in clayey soil, this species was only controlled in higher doses. For Euphorbia heterophylla L. and Ipomoea grandifolia Dammer, the control was more efficient in the loam-clay-sandy soil.

This demonstrates the lower amount of clay in soil can result in less adsorption of indaziflam and greater availability of the product in soil solution, making it available for absorption by weeds and for transport, such as leaching (Alonso et al., 2011).

Therefore, coffee litter contains both organic matter and lipids, favoring the adsorption of indaziflam, and decreasing the amount of product that reaches the soil solution and is available for transport processes. In contrast, the sandy soil used in this study, with only $25.2 \%$ clay, has a lower adsorption of indaziflam along the soil depth, a fact that can potentiate the leaching of indaziflam along the soil column. This behavior justifies the greater leaching of indaziflam when applied directly to the soil under $40 \mathrm{~mm}$ simulated rainfall.

Jhala, Ramirez and Singh (2012) registered the increase in leaching in soil columns with increasing amounts of rainfall. For example, indaziflam leached up to $0.12 \pm 0.008 \mathrm{~m}$ (mean $\pm \mathrm{SD}$ ) and $0.27 \pm 0.026 \mathrm{~m}$ under simulated rainfall of 0.05 and $0.15 \mathrm{~m} \mathrm{ha}^{-1}$, respectively.

$U$. plantaginea showed high susceptibility to chemical control by indaziflam, because regardless of the amount of straw or simulated rainfall after application, the control was greater than $80 \%$. Nevertheless, as well as the data obtained in the leaching experiment, the application of indaziflam on larger amounts of straw combined with lower amounts of rainfall reduced the effectiveness of indaziflam in controlling $U$. plantaginea.

These results reinforce the lipophilic nature of indaziflam and indicate that applications on larger amounts of litter followed by smaller amounts of rainfall after application 
can result in less effective control (Gonzales-Delgado et al., 2015), due to the reduction of the movement of the herbicide from the litter to the planting site of $U$. plantaginea seeds.

Da Silva et al. (2020) investigated the control of $U$. plantaginea in situations of indaziflam application on sugarcane straw, and verified control percentages above $80 \%$ in applications on $0 \mathrm{t} \mathrm{ha}^{-1}$ straw; the control was lower in the largest amounts of straw. The authors also verified the high susceptibility of $U$. plantaginea to indaziflam (100 g a.i. ha $\left.{ }^{-1}\right)$, since at $35 \mathrm{DAE}$ (days after emergence), regardless of the amount of straw and rainfall, the control was greater than $90 \%$.

Another relevant aspect that should be mentioned is that during the whole experiment, the experimental units had high moisture, favoring the constant availability of indaziflam in soil solution and consequently increasing its effectiveness in controlling $U$. plantaginea. This indicates that the application of indaziflam on coffee litter followed by intervals without rainfall, may result in less effectiveness of the product in controlling weeds (Da Silva et al., 2019).

Malardo et al. (2017) observed that the efficacy of indaziflam $\left(0.07 \mathrm{~kg}\right.$ a.i. $\left.\mathrm{ha}^{-1}\right)$ in controlling Eleusine indica and Chloris polydactyla was lower when the $20 \mathrm{~mm}$ rainfall occurred 10 days after application, concluding that the presence of straw and the dry period interferes with the effectiveness of the herbicide.

\section{CONCLUSION}

Given the above, it can be concluded that the increase in the amount of litter on the soil surface, combined with lower amounts of simulated rainfall may reduce the transposition of the herbicide initially applied on the litter and/or soil surface, thus reducing its incorporation in relation to depth, a fact that can interfere with the effectiveness of weed control.

\section{REFERENCES}

ALONSO, D. G. et al. Sorption-desorption of indaziflam in selected agricultural soils. Journal of Agricultural and Food Chemistry, 59(24):3096-3101, 2011.

AMIM, R. T. et al. Weed Control with indaziflam in soils with different physico-chemical attributes. Planta Daninha, 32(4):791-800, 2014.

ASOCIATION LATINOAMERICANA DE MALEZAS ALAM. Recomendaciones sobre unificación de los sistemas de evaluación em ensayos de control de malezas. ALAM, Bogotá, 1(1):35-38, 1974.

BARBOSA, J. C.; MALDONADO JÚNIOR, W. AgroEstat versão 1.0 - Sistema de análises estatísticas de ensaios agronômicos. Universidade Estadual Paulista, Campus de Jaboticabal, SP, 2009. 396p.
BROSNAN, J. T. et al. Pre and post emergence annual bluegrass control with indaziflam. Weed Technology, 26(1):48-53, 2012.

BROSNAN, J. T.; MC CULLUOGH, P. E.; BREEDEN, G. $\mathrm{K}$. Smooth crabgrass control with indaziflam at various spring timings. Weed Technology, 25(3):363-366, 2011.

CARVALHO, L. B.; ALVES, P. L. C. A.; BIANCO, S. Sourgrass densities affecting the initial growth and macronutrient content of coffee plants. Planta Daninha, 31(1):109-115, 2013.

CLARK, S. L. et al. The influence of winter annual grass litter on herbicide availability. Weed Science, 67(6):702709, 2019.

DA SILVA, P. V. et al. Chemical control strategies of Commelina benghalensis in coffee crop. Coffee Science, (14):231, 2019.

DA SILVA, P.V. et al. Efeito da palha de cana de açúcar e da precipitação na eficácia do indaziflan. Revista De Ciências Agrárias (Lisboa), (42):1040-1051, 2020.

DIAS, T. C. S.; ALVES, P. L. C. A.; LEMES, L. N. Interference periods of Commelina benghalensis after coffee establishment. Planta Daninha, 23(3):398-404, 2005.

GONZALES-DELGADO, A. M. et al. Mobility of Indaziflam Influenced by Soil Properties in a Semi-Arid Area. Plos One, 10(5):1-12, 2015.

GUERRA, N. et al. Persistence of Biological Activity and Leaching Potential of Herbicides Aminocyclopyrachlor and Indaziflam in Soils with Different Textures. Planta Daninha, (34): 345-356, 2016.

JHALA, A.J.; RAMIREZ, A.H.; SINGH, M. Leaching of indaziflam applied of two rates under different rainfall situations in Florida Clandler Soil. Bulletin of Environmental Contamination and Toxicology, 88(3):326-332, 2012.

KÖPPEN, W.; GEIGER, R. Klimate der Erde. Gotha: Verlag Justus Perthes, 1928. 404p.

MACIEL, C. D. G.; VELINI, E. D. Simulation of rain wetting dynamics and herbicide movement in different straws used under no-tillage system. Planta Daninha, 23(3):471-481, 2005.

MALARDO, M. R. et al. Influence of the sowing depth and amount of sugarcane straw on the emergence of Chloris polydactyla and Eleusine indica and their control by herbicides applied pre-emergence. Semina: Ciências Agrárias, 38(3):1187-1200, 2017. 
OLIVEIRA, A. R.; FREITAS, S. P.; VIEIRA, H. D. Interference of dayflower species in coffee culture. Planta Daninha, 27(4):823-830, 2009.

RODRIGUES, B. N.; ALMEIDA, F. S. Guia de herbicidas. $7^{\mathrm{a}}$ ed., Londrina, 2018. 697p.

RONCHI, C. P.; FERREIRA, R. T.; SILVA, M. A. A. Manejo de plantas daninhas na cultura do café. In: MONQUERO, P. A. (Org.). Manejo de plantas daninhas nas culturas agrícolas. São Carlos: RiMa Editora, p.132-154, 2014.

RONCHI, C. P.; SILVA, A. A. Tolerance of coffee plants to post emergence herbicide application. Planta Daninha, 21(3):421-426, 2003.
SANTOS, H. G. D. et al. Sistema brasileiro de classificação dos solos. 5.ed. Brasília: Embrapa, 2018. 355p.

SEBASTIAN, D.; NISSEN, S.; DE SOUZA RODRIGUES, J. Pre-emergence control of six invasive winter annual grasses with imazapic and indaziflam. Invasive Plant Science and Management, 9(4):308-316, 2016.

SILVA, P. V.; MONQUERO, P. A. Straw influence on chemical weed control in raw sugarcane system. Revista Brasileira de Herbicidas, 12(1):94-103, 2013.

TOMPKINS, J. Pesticide fact sheet: indaziflam. United States, Environmental Protection Agency, 2010. Available in: $<$ http:// www.epa.gov/opp00001/chem_search/reg_actions/registration/ fs_PC-80818_26-Jul-10.pdf $>$. Access in: March, 28, 2018. 